\title{
Sciendo
}

\section{STAGING SUSTAINABILITY AT EXPO 2000: GERMANY'S PANACEA FOR THE CRISES OF CAPITALISM}

\section{SERGIU NOVAC 1}

\begin{abstract}
This article explores how sustainability was staged in the context of EXPO 2000, the first and only world exhibition organized by Germany. The notion seemed to gain ground around the turn of the millennium in global political and policy circles, especially through such documents as the 'Agenda 21' and the 'Millennium Development Goals'. These were also the main source of inspiration while organizing EXPO 2000, which, under the motto 'Humankind, Nature, Technology' claimed to put forward a radically different vision for the 21st century. However, throughout the paper I argue that sustainability ended up performing a quite different ideological function. In Germany, the staging of sustainability took place as an activation of expertize, meant to fix a crisis of the economy and to open up new grounds for capitalism's search for profit, ultimately deepening the environmental crisis that it was meant to alleviate in the first place.
\end{abstract}

Keywords: sustainability, Agenda 21, EXPO 2000, Germany, Birgit Breuel

Today, the Dutch pavilion is one of Hannover's few remaining landmarks of EXPO 2000. The open, four-story, concrete building is a ruin. Wild weeds have taken over, turning it into a statement for the passage of time. If intended, this abandonment would have been very fitting to the initial theme of EXPO 2000, which set out to envision new forms of interaction between humans and nature for the future. As if being a project of the French landscape architect Gilles Clement, the Dutch pavilion would have stood as a reminder of the resilience of 'nature' and the contradictions of culture, understood as work performed by humans on nature ${ }^{2}$.

${ }^{1}$ Department of Sociology and Social Anthropology, Central European University, Budapest, email: Novac_sergiu@phd.ceu.edu.

2 Clement, through his 'Manifesto for the Third Landscape' (2015), makes a claim for noninterventionist urban rewilding of interstitial places, which are considered as not important by humans. His paradigmatic project exemplifying this idea is the Matisse Park in Lille. Another project that experiments with this idea is the High Line in New York. For more details, see Matthew Gandy's paper (2013) on the topic. 
The first and only World Exhibition hosted by Germany in the city of Hannover, the capital of the state of Lower Saxony, tackled the topic of sustainability. It attempted to bring nature into the field of technological development and resolve the contradictions between the two through novel approaches.

However, the abandonment of the Dutch pavilion was unintended. An article in the main local newspaper from Hannover drew attention in 2016 upon the state of the buildings left behind by the world exhibition, being particularly concerned about the Dutch pavilion. It deemed it as a 'rotten' risk to public safety and argued for it being demolished as soon as possible (von Meding, 2016). Furthermore, the initial concept behind the Dutch pavilion did not have anything in common with Clement's ideas. Under the motto 'Holland creates space' the project engaged with the continuous struggle of a country with limited space against nature. The website of the planning office that designed the pavilion described it as 'six stacked Dutch landscapes, which form an independent eco-system, communicating cultural sustainability: progressive thinking and contemporary culture are combined with traditional values' 3 . The visitor would encounter windmills, forests and tulips on different floors, each encased in thick layers of concrete. The Dutch pavilion was considered one of the most successful exhibits of EXPO 2000 and received one of the largest numbers of visitors among all pavilions (See Fig. 1).

The questions that I will be concerned with throughout this paper is what kind of sustainability was staged at EXPO 2000 in Germany and to what effect? A first hint towards answering the first question can be found in the story of the Dutch pavilion: EXPO staged sustainability as a complex of highly engineered monocultures, encased in thick layers of concrete. However, there is more to it. In this article, I argue that sustainability had an important role in addressing the 1970 s crisis, but in doing so it rather obscured the real reasons for the crisis and enabled - at least at discursive level - an important shift towards reform at the level of German high politics. In other words, by staging sustainability in a particular way, after the year 2000 Germany was able to activate both environmental reforms and the most far reaching labour market reforms since the Second World War. I argue that these two go hand in hand and are the consequence of a particular understanding of fixing the longue durée crisis of the 1970s.

3 (“MVRDV - EXPO 2000" 2017). 
Figure 1.
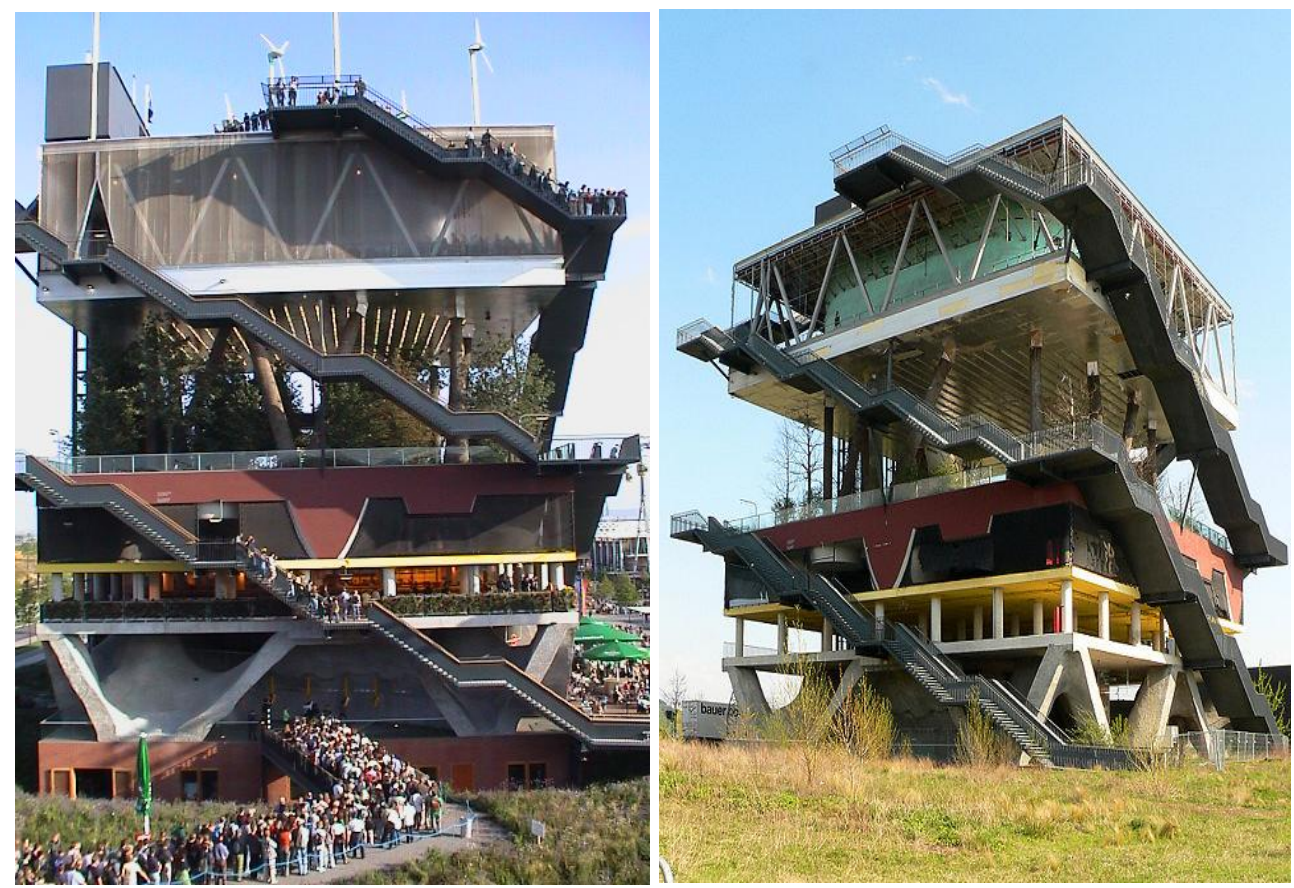

Left: Dutch Pavilion during the EXPO (Source: Juergen G., 2000, Wikipedia, CC License); Right: Dutch Pavilion after the EXPO (Source: Axel Hindemith 2008, Wikipedia, CC License).

In the first part of this paper, called 'Crisis 2.0', I explore the context of organizing the EXPO 2000 and the intellectual inspirations that were brought in for staging it. My argument is that Germany used to opportunity of EXPO 2000 to take up a leading role in fixing the problems of the environment. The interesting question is how this happened and what exactly sustainability ended up meaning in this context. By closely analysing the political context around EXPO and the specific intellectual traditions that were employed in justifying sustainability, I argue that sustainability operated as a discursive device deployed by a set of carefully selected experts in order to open up new terrains for capitalisms ever-expanding ambitions.

The second part, called 'Crisis 1.0' then goes back to the 1970s and does a political biography of the general manager of EXPO 2000, Birgit Breuel, in order to trace the becoming of this specific market oriented vision of sustainability. 
The story that is being told here is very particular to the German context and oscillates between state level - Lower Saxony - and federal level. However, the trajectory of the notion of sustainability, understood as a millennial catch-all fix for the deepening crisis between capitalism and nature, will show clear resemblances with other cases from around the world, cases about which this article hopes to trigger a future conversation.

\section{Crisis 2.0: Sustainability at the EXPO 2000}

Under the motto 'Humankind, Nature, Technology - A New World Arising', the featured projects of EXPO 2000 tried to imagine a future articulated along the principles of 'Agenda 21', the working paper developed at the Rio Summit in 1992 for the $21^{\text {st }}$ century. Next to the standard format of projects exhibited on site in Hannover, for the duration of EXPO several other exhibits were organized around Germany and internationally. They were supposed to function as real-life laboratories, examples of already ongoing attempts of shifting towards more sustainable ways of living. Birgit Breuel, the general commissioner and manager of the EXPO, underlined the importance of the connection between the EXPO and the Agenda 21 tirelessly in all the official documents that were produced in the context of the event.

It has taken Germany 150 years to organize the world exposition for the first time. This is something we can be proud of (...). What motivates the EXPO 2000, as far as content is concerned, is Agenda 21, a campaign for the $21^{\text {st }}$ century voted in at the first Environmental Summit held in Rio de Janeiro in 1992. The 179 signatory states undertook to commit themselves to the principle of sustainable development, combining economic capacity, social responsibility and resource-preserving behavior. (EXPO 2000 2000, 15)

The bid for the EXPO 2000 was won by Hannover in the late 1980s. At that time the ruling party at the level of the state of Lower Saxony was the CDU 4 . They had been in power at the state level since 1978. But soon after the bid was won the party would be voted out of power and a new coalition between the SPD $^{5}$ and the Green Party would take over 6 . The new coalition took it upon itself to find a topic for the EXPO 2000, which would break completely with the tradition of progress that previous world exhibitions staged. EXPO 2000 was supposed to be a platform for ideas that would solve the problems of the $21^{\text {st }}$ century, beyond established Cold War binaries. While promoting the future

\footnotetext{
4 The Christian Democratic Union of Germany.

5 The Social Democratic Party of Germany.

${ }^{6}$ At federal level the CDU would remain in power under Helmut Kohl until 1998.
} 
EXPO to local actors in the Hannover region in 1991, the at that time new prime minister of Lower Saxony, Gerhard Schröder, took stock of former world exhibitions and expressed clearly what Hannover should not do: 'There is a common underlying notion of all world exhibitions: the taken for granted connection between technical progress and a future painted in bright colors' (Schröder, 1992: 5). A world exhibition is a commercial endeavour and Schröder was trying to persuade the otherwise rather sceptical local actors from the city and region of Hannover to become involved in organizing the EXPO. But in doing so he appealed to a set of arguments that expressed the importance of Germany having the chance to organize the turn-of-millennium world exhibition. In words that could have been taken out of Adorno's and Horkheimer's (1973) classic of critical theory, Schröder referred to the 'exceptionality' of Germany in dealing with history and to the lessons that it could bring into a new vision of the future, having this particular historical consciousness.

Man's emergence from his self-imposed non-age through the jump into Enlightenment seemed unbroken for a period of several decades. Yet, at least since the catastrophic experience of the two world wars of this century and the systematic mass destruction by fascism, optimistic progress has become impossible. Enlightenment today has a different meaning. A world exhibition at the end of this century has to face the past. Without a balance sheet of modernity - by this I refer to the past 200 years since the French Revolution the future is unthinkable. (Schröder, 1992: 5-6)

This is not Kant speaking, nor is it Adorno, but Gerhard Schröder, a trained politician presenting himself at his best, both pleasing his Green Party coalition partners by posing as a reformed social democrat concerned with environmental issues, and by impressing his audience by referring to the exceptionality of Germany with regard to the memory of the Second World War. In the same speech from 1991, he went on and asked for a 'World Exhibition of a completely new kind' (Schröder 1992, 12) which, on one hand, would embrace a critical distance towards past exhibitions, by having a more pronounced historical reflexivity and, on the other hand, would give space for conflict and critical dialogue:

A World Exhibition which wants to be faithful to the situation of the world at the end of the $20^{\text {th }}$ century has to represent social, ecological and cultural needs of people, has to be a forum for discussions coming from different directions, but also has to be tolerant enough in order to put contradictions alongside each other. (Schröder, 1992: 13) 
Conflict and critical debate would be possible only under the prerequisites of a basic conviction: 'The utopian hope for a global community, which works in solidarity towards solving its problems and conflicts' (Schröder, 1992: 18). On the very same page, Schröder managed to speak against Kant by revealing the internal contradictions of the Enlightenment project, while finally returning to the Kantian notion of a 'global community' as a platform where these contradictions should be discussed and solved.

Schröder, the up and coming politician, was at his best here. The dilemma of finding a proper theme for the EXPO 2000, beyond the mentioned contradictions, was real. If we were to read these speeches in another light, the question that was posed was to find a theme of global relevance at a time when conservative global intellectuals where celebrating the end of 'big themes'. While the prime minister was giving his speeches, the 'end of history' (Fukuyama, 1992) was arriving, the Soviet Union was in full collapse and capitalism was finally triumphant. Lyotard's (1992) prediction about the end of grand narratives seemed to have fulfilled itself. In this confusing and rapidly changing context, finding a theme of global relevance for the EXPO 2000 was indeed a challenge. Especially for a party coalition from the centre-left which tried to go against the mainstream conservative atmosphere of the time, but also against the CDU, which was still in power, under Helmut Kohl, at the federal level.

One year after Schröder's speech an event of global importance offered the opportunity for a theme of such relevance. The 1992 United Nations Conference on Environment and Development held in Rio de Janeiro, otherwise called the Earth Summit, made sustainability a priority for policy-making on a global level. The most important document that emerged from the conference, the Agenda 21, started out by stating:

Humanity stands at a defining moment in history. We are confronted with a perpetuation of disparities between and within nations, a worsening of poverty, hunger, ill health and illiteracy, and the continuing deterioration of the ecosystems on which we depend for our well-being. However, integration of environment and development concerns and greater attention to them will lead to the fulfilment of basic needs, improved living standards for all, better protected and managed ecosystems and a safer, more prosperous future. No nation can achieve this on its own; but together we can - in a global partnership for sustainable development.

The Agenda 21 acknowledged the growing global disparities and the challenges faced for development. The grand narrative that was proposed in order to alleviate this problem, the fix for the internal contradictions that Schröder was talking about, should be sustainability. The arrival of a global 
agenda for the $21^{\text {st }}$ century presented a unique opportunity for the organizers of the EXPO 2000 and the Agenda 21 became the blueprint around which the entire world exhibition was organized. After having dealt with the German reunification throughout the 1990s, Germany wanted to show that it was now ready to take up a leading role on the global policy agenda.

I will now turn to some of the main intellectual inspirations around which the notion of sustainability was articulated in the context of world exhibition. In the year before EXPO a series of books were published by the organizers at the prestigious German academic publishing house Campus, each tackling one specific sub-topic of the exhibition. They were edited and written by world renowned experts in their specific fields, in order to give them additional weight. The first, edited by Birgit Breuel, the general manager of the EXPO, had the name 'Agenda 21. Vision: Sustainable Development' (Breuel, 1999). In it, she traced the intellectual roots of the agenda and the turn towards sustainability in a very specific moment of crisis:

The technological progress displayed by world exhibitions and the corresponding development of societies in western nations were mainly dependent since 1851 on the ever-accelerating exploitation of Earth's limited resources. (...) The report of the Club of Rome from the year 1972 about 'The Limits to Growth' tackled for the first time for a broader audience the fact that this pattern of resource use will reach clear limits and that development can't go on as it did before (...) However, the basic argument of this first report for the Club of Rome about the 'Limits to Growth' stands until today: The natural resources of the Earth are limited and the cumulated global consumption became so high that we can't even afford the mid-term continuation of this path. These thoughts were picked up in a different manner by the UN Conference for Environment and Development in Rio in the year 1992 and the concept 'sustainability' was added to future development. Practically all nations of the world undersigned the 'Agenda 21', which was decided at this conference. (Breuel, 1999: 9)

Crisis was therefore pinpointed in a specific historical moment, in the context of the publication of the book 'The Limits to Growth' (1972). Starting from this moment, Breuel argued, a signal was given to think about the relationship between human development, technology and nature in a different manner: 'Agenda 21 is often also called the "Environmental Paper". However, "sustainable development" involves much more than just careful use of natural resources. It involves also the living and acting together of humans.' (Breuel, 1999: 9). Along with the book edited by Breuel, an entire set of books on the separate topics of the EXPO were published, on topics such as climate change, health, global food supply, labour or energy. 
Take, for example, the book on energy written by Amory Lovins in collaboration with Peter Hennicke for the EXPO. Under the title 'Full of Energy: The global factor four strategy for climate protection and nuclear exit' (1999) the two authors set out to present a new energetic future for the $21^{\text {st }}$ century. Peter Hennicke was at the time the head of the Wuppertal Institute for Climate, Environment and Energy, the most prestigious German institute in the field. Lovins was by that time a world famous public figure. He had been advocating since the 1970s, through the Rocky Mountain Institute in the US, for a soft path transition towards renewable energy sources. The 'factor four' strategy which they proposed in their book is one in which it is argued that economic growth does not necessarily have to be coupled with growth in energy use. Therefore, it is possible to halve the energy use, all the while doubling the productivity of the economy. The underlying principle follows a strong belief in technological fixes, that would enable this strategy. In the first part of the book, Lovins and Hennicke set out to show why fossil energy sources do not have a future. The main reason they pinpoint at here follows in the footsteps of the Club of Rome report, arguing that they are finite resources and that their continued exploitation harms the environment. Then they move on to explain why nuclear energy is not an alternative to fossil fuels and should not be considered as an alternative. Here they underline mainly the risks of nuclear energy and the environmental and health impacts of the waste produced. Finally, they turn to possible future scenarios, modelled until the year 2050, showing that their 'factor four' alternative is the most feasible. With such examples as a shift towards regional smart grids, solar and wind energy production facilities, electric cars and passive houses, the authors try to convince the reader that a total reshaping of the global energy landscape is possible, without having to change anything in lifestyle. They also explain that 'climate protection' is, firstly, an opportunity for more profit, and should be approached accordingly by involved actors in the energy sector:

Put simply, most methods for preventing climate change are better from many perspectives: they are profitable, not against the equilibrium of the planet, but, quite the contrary, of crucial importance - they serve development, well-being and safety. Additionally, they do not depend on top down interventions, but are based on the intelligent use of market forces. The result of climate protection is not suffering, deprivation and sacrifice, but profit, enterprise spirit, innovation and advantage through increased competitiveness. (Lovins and Hennicke, 1999: 102)

Lovins and Hennicke expose here a strong belief in the fact that market forces not only provide the only solution to climate change, but that they also will promote business interests and bring profit to all market actors involved. 
However, surprisingly, they also claim that this view runs contrary to the one expressed by neoclassical economics.

Today we begin to step over the traps that neoclassical economic theory has laid ahead of us. It started from the premise that it is expensive to economize on or replace certain resources - and that it becomes more and more expensive, the more one want to give up on them for the sake of the environment. However, the 'new growth theory' describes the previously unthinkable possibility to transform thinking into rising profits - based on exponentially growing knowledge about the interactions in a system. (Lovins and Hennicke, 1999: 104)

The only problem is that it is not at all clear what the 'new growth theory' should be about, and in what way exactly it is different than neoclassical economics. Not having laid out a critique to neo-classical economics, the 'factor four' strategy presented here seems to be rather a fix to the intrinsic problems of economics, and not a radical alternative. It is important to remember why, in the context of this article, the choice of giving voice at EXPO 2000 to an expert like Amory Lovins was relevant. Lovins' engagement with the energy crisis was not singular in the 1970s - he represented one faction of experts in a highly dynamic and controversial field of debates surrounding the future of the earth's resources and the possibilities of alternative modes of conviviality. Other thinkers that engaged with the topic at that time had a very different approach to the topic. For Ivan Illich, to take just one famous example, technological development was just another illusion that deepens the relations of slavery among people and between people and their environment. For Illich, 'high quanta of energy degrade social relations just as they destroy the physical milieu.' (1974: 15) But in the context of the EXPO, such a critique was too radical and a solution which advocated for technological fixes, while at the same time favouring profit maximization was more preferable. The view of innovative, enterprise oriented actors on the market, all struggling to maximize their profit, while at the same time protecting the planet, was only one from a longer series of absences. Another one, equally important, was the complete absence of labour from the discussion.

The EXPO 2000 book series had another book, fully dedicated to labour. Unfortunately, there was no connection between the two. The author of the second, German sociologist Ulrich Beck, chose to entitle it 'The Brave New World of Work' (Beck, 1999). The reference to Huxley's famous dystopian novel wanted to be ironic, warning the reader from the outset that this is not a topic with easy solutions. Beck choses to start his intervention with a peculiar and rather unfortunate description of the state of the world, by deploring the 'brazilianization' of the West. His claim is that Western societies, which have 
been the 'bastions' of full employment for decades, are increasingly shifting towards a model of partial employment, just like it is in the norm in the Global South. Not only is this a strange argument to make in a book that is part of a World Exhibition, celebrating new ways of working together between nations, but it also obscures decades of interventions by international, 'western' global financial institutions in the economies of the countries of the Global South.

Starting from this unfortunate term, Beck embarks on an otherwise necessary discussion, which was completely absent in the context of the EXPO. It involves what he calls 'the end of work society': the way neoliberalism unfolded an explicit attack on labour in the past decades. Continuing his ideas from previous books, Beck argues that the demise of work society also signals the entrance into a new era, that of the 'risk society', defined by a 'political economy of insecurity', in which nation states and localized labour find it hard to adapt to the rapid flexibility of global capital and such notions as labour flexibility and market deregulation become the norm (Beck, 1999: 7-11). These phenomena are the trademarks of a 'reflexive modernization'.

The term 'reflexive modernization', then, refers to the transition away from a first modernity locked within the national state, and towards a second, open, risk-filled modernity characterized by general insecurity. This transition takes place, as it where, within a continuity of 'capitalist modernization', which is now in the process of removing the fetters of the national and the welfare state.

(Beck 1999, 24)

But this is just as far as Beck goes in his analysis. He remains at the level of intuitive descriptions, criticizing Thatcher for the open attack on 'society' and foreseeing a classless society in the 'risk society'. He then describes nine possible scenarios of how the 'risk society' will actually look like. Most are bleak, with descriptions such as 'global apartheid' or 'individualization of work disintegration of society' (41). Not surprisingly, Beck does not include any form of socialist organization of society in his 'future scenarios', not even in the category of negative possible outcomes, all the while quoting extensively authors like Andre Gorz and Ivan Ilich in his book and arguing for the possibility of a world where paid work is not a necessity. His two future scenarios that are of a 'radical optimism', as he claims, involve the future of Europe and the future of the world. For Europe, he claims that starting with the collapse of state socialism the world does not operate in bipolar terms anymore and there is finally a free exchange of ideas. This is facilitated by a form of capitalism which has a multitude of forms, facilitating 'multiple, coexisting modernities', which can nurture a rich exchange of ideas (123). Specifically, Beck imagines the future of Europe as a future based 
on a model of 'civil labour', which would exist in tandem with paid, unsatisfactory labour and would compensate on the needs of social cohesion and self-worth of a 'society of citizens' (128). And for the world, Beck argues that the best option in the 'risk society' would be a 'post-national civil society', which would be the harbinger of new forms of solidarity and a new consciousness for global problems such as climate change (151). Just as Schröder had concluded his speech for promoting the EXPO in 1991, Beck ends his long expose with the enthusiastic claim: 'Cosmopolitans of the world, unite!'

The work society is drawing to a close, as people are more and more replaced by smart technologies. Must this all lead to catastrophe? No, on the contrary: only when all passive toil at machines has been successfully done away with, will human creativity be free to answer in detail the great questions of the second modernity. Whether it will be done successfully or not, no one can say. So why should we only be either pessimistic or optimistic, and not both at once? For the question of whether a European cosmopolitan movement is capable of becoming reality can find an answer only where it belongs - in the practical space of politics. This would then realize one of the main ideas of Kant's Perpetual Peace: 'To consider oneself, according to internal civil right, as an associate member of a cosmopolitan society is the most sublime idea anyone can have of their destination. One cannot think of it without enthusiasm.' (Beck 183) ${ }^{7}$

The EXPO 2000 therefore pinpointed a real, urgent global problem. I do not intend to argue here that the problem was not of serious concern - quite the contrary! Rather, the way it was represented and the solutions offered to solve it were, at best, superficial. None of the pavilions of EXPO or the intellectuals recruited to give weight to its main theme engaged with capitalism as a possible problem of the environmental crisis. Naturally, none about to imagine a world beyond capitalism where the relation between humans, nature and technology could be different. Quite the contrary, in the short period from the signing of the Agenda 21 and EXPO 2000 a set of global experts were mobilized to transform sustainability into a catch-all market fix that would cure the crisis of the global economy. However, the underlying reasons for the crisis were largely left undisputed and the same people that had been active in creating it, were now active in supposedly fixing it through sustainability. It does not come as a surprise that the outcome of this gigantic representational spectacle, which culminated in EXPO 2000, ended up being just a very temporary fix.

\footnotetext{
7 Interestingly enough, in the English translation of the book Beck quotes Kant, while in the original German version he chooses to end the article with a quote from Nietzsche (Beck, 2000).
} 
However, at least in the German case, organizing this spectacle proved to be a smart political move. By the time that the EXPO 2000 was organized, Gerhard Schröder and his SPD/Green Party coalition had moved from governing the state of Lower Saxony to governing the entire German Federation ${ }^{8}$. The EXPO 2000 turned into the blueprint of this new government.

\section{Crisis 1.0: Privatization, flexibilization and German re-unification}

Thus far I have shown how both the Agenda 21 and the organizers of the EXPO pinpointed the emergence of an unfolding crisis somewhere in the 1970s and explained it through a mismanagement of the Earth's resources. However, the crisis unfolding in the 1970s had a broader significance, and resource exploitation was just one part of it. The post-war economic boom period was coming to an end and it was threatening to destabilize the political consensus of the Western, developed nations. The formation of OPEC, decolonization, rising oil prices and the decoupling of the dollar from the gold standard marked the end of the Bretton-Woods agreement. Simultaneously with the unfolding economic crisis, Keynesian economics started to be heavily disputed in elite universities - especially in the US. By the late 1970s a major tectonic shift had happened in the elite policy circles of the West. The conservatives were coming back to power, but this time with a new ideological agenda. Reagan in the US and Thatcher in the UK provided the political support for a shift in the ideological disposition of the most important control mechanisms of the global economy, such as the IMF and the World Bank. This move involved deregulating trade and finance, rolling back public spending and weakening organized labour.

Germany was fully immersed in this process. As the 'contradictions of the welfare state' (Offe, 1984) were unfolding, the 'social market economy', a fundamental notion of the German post-war welfare pact between the two big parties, was coming under threat. After a very long hold on power at federal level by the social democrats (1969 - 1982), the conservative party moved in and attempted the same kind of reforms as those being implemented in the UK by Thatcher or in the US by Reagan. Heated debates started inside the CDU around this topic and a new faction of conservatives, with a strong liberal, promarket economic ideology, was emerging. A key figure in this faction was none other than Birgit Breuel, whom we have already encountered as the general manager of the EXPO 2000.

\footnotetext{
${ }^{8}$ Schröder's government took office in 1998. This was also the first and only period that the Green Party was in power at federal level, between 1998 and 2005.
} 
In order to be able to explain what sustainability activated in the context of Germany, we will have to return back in time, to this specific moment of crisis. This is of course a very dense story and it is impossible to narrate the history of German politics in the last fifty years in the context of this paper. I will therefore stick to the figure of Birgit Breuel, and read the history of staging sustainability through her own political career. Although relatively unknown outside of Germany, Breuel is important to the story of sustainability because she has played the role of a crisis fixer repeatedly and has tirelessly advocated for a very specific type of reform articulated around the mantra of privatization, flexibilization and de-bureaucratization. In this last part of the article, I will show why this mantra was particularly fitting to the vision of sustainability outlined in the context of EXPO 2000.

The appointment as general commissioner of the EXPO 2000 was Breuel's last important publicly held position. But by that time she had already established a long-standing career as one of the most important CDU politicians of the country. Breuel came from a rich, conservative family of bankers from Hamburg, with her father, grandfather and great-grandfather being in the parliament of the city-state. She entered politics in 1971 as a member of the Hamburg parliament, becoming the speaker of the CDU in the economic committee of parliament. She was the first woman in the family to go into politics. In 1978 she moved to the state of Lower Saxony, becoming Minister for Economy and Transportation in the newly appointed CDU government of Ernst Albrecht. It was because of her that the feminine form of the word minister (Ministerin) was officially used for the first time in German politics. She held this position between 1978 and 1986 and in the last mandate of Ernst Albrecht she held the office of Minister of Finance (1986 - 1990).

Next to her activity as a politician, Breuel also became an active writer. She published several books during this period, in which she exposed her political views. Already before becoming a minister in Lower Saxony, Breuel published a book with the title 'There is no buttered bread for free'9 (1976), in which she exposed her ideas about the unfolding global economic crisis and the chances of the German economy in this context. It is important to note that, at this point, Breuel and her party were still in the opposition at federal level. What she argued for was therefore also directed against the politics of the ruling SPD. The underlying idea of this first book, an idea which she would develop in the following years, was that the state intruded all areas of life, crunching entrepreneurialism in the private sphere, blocking competitiveness in the economic sector and hindering innovation. The solution to the unfolding crisis,

\footnotetext{
9 'Es gibt kein Butterbrot umsonst' (Breuel, 1976)
} 
which she compared to the great depression of the 1930s, was to gradually shrink the state, in order to promote efficiency and competitiveness: 'This means, concretely, that political forces must work together, with small steps, towards a greater participation of private individuals and towards greater preparedness for risk' (Breuel, 1976: 120).

Her second book (Breuel, 1979) follows on the same path and is an open attack towards bureaucracy, understood here as a 'fungus' that encroaches on all spheres of life, especially on the market, blocking its proper functioning. The book is split into two parts, the first being a critical assessment of the present situation, the second being a proposition for an alternative future. The situation that Breuel describes is one dominated by suffocating bureaucracy, while the solution for an alternative, better future is a society that promotes the private initiative of individuals. In Breuel's own words: 'Social means in the first place the chance of freely unfolding the self. It should not be reduced to social aid.' (1979: 83)

The following year (Habermann and Deimer, 1980) she was part of an editorial group for another book called 'Anti-bureaucracy: More citizen than slave'. Together with a group of economists promoting a similar line of thinking, in this book the state was deemed as the 'Leviathan', which had to be properly dealt with in order to get Germany going again.

The book is a warning for everyone to think whether they do not ask for more state care through their behaviour and whether they would like it, if state structures are available with their services around the clock (...) Put differently: We are all producers of bureaucracy and it would be catastrophic if we would forget this and look for the reason for more state in another, anonymous sphere (...) I transitioned during the writing of this book from the Hamburg Parliament to a ministerial office in the Lower Saxony government. Immediately after I took up office in the Ministry for Economy and Transport, I set up a new bureau which is exclusively concerned with the issue of privatization. ${ }^{10}(12)$

Starting with the moment of transitioning to power, together with the CDU, in Lower Saxony, a new topic figures high on the agenda: privatization. Simultaneously, on federal level, the CDU moves into power and Helmut Kohl becomes the chancellor of Germany. The position from which Breuel expresses her ideas from now on is that of the ruling party, both at federal level and at the level of the state of Lower Saxony.

In 1983 she published a book called 'Perspectives for Awakening: Learning from Mistakes'. Here Breuel expands her case for a free market economy against state interventionism, pointing out four key sites on which work

10 My own indent. 
had to be done: the strengthening of market elements, more private initiative coupled with more private responsibility (flexibilization), privatization and debureaucratization. She ends the book with the quote from Seneca, "life means struggle' (1983: 203), suggesting that there is no other way for creativity and freedom to develop than through deregulated market competition.

Breuel seemed to be constantly up to date with the most recent debates in the German public sphere of the time, never failing to engage them in her writings. In 1985 she declared that the world was entering a post-industrial age and declared that she was fully committed politically to embracing the structural changes of society, including the painful consequences of losing some of the old, established industries (Breuel, 1985). Furthermore, she actively engaged social scientists and explained how they also have to participate in this process of shaping new kinds of political subjectivities. In the opening speech that she gave to the Annual Congress of the Association of Market and Social Researchers (1986), Breuel pointed out the unfortunate lack of communication between technological and social research. She argued that this lack of communication had to be overcome in order to properly address Germany's future:

The core question of Germany's future is how can we connect progress in technological fields with that of social and human progress? How can we adapt technological developments and their implementation in companies also for developing social structures? ${ }^{11}$

Breuel seemed unaware of the taylorist undertones that her statement had and went even further, describing how such a move might be possible. One aspect she identified was that of education and professional formation, where she argued for an early education towards flexibility on the labour market and lifelong learning strategies. When addressing work and free time, she discussed social innovations that would be required in order to make individuals adapt to technological progress. She then engaged with a series of sociologists Dahrendorf, von Nell-Breuning and Peccei - and showed that even they complained about the fact that 'official wage labour' is the only form of recognized labour (Breuel, 1986: 16-19). In this context, she referred to a series of types of work that are done by women. And yet, it would be a mistake to think that Breuel was making an argument for introducing wages also in the domain of unpaid, mostly care work done by women. Quite the contrary, she summoned sociologists to find ways to raise the social worth of this type of work, without it being paid: 'We must consider ways through which we can raise the social prestige of unpaid work, in order to guide the transformation process of our society to our advantage.' (1986: 19).

11 My indent. 
It comes as no surprise that Breuel had been often compared to Margaret Thatcher during those years. Thatcher's 'there is no such thing as society; there are only individual men and women. And there are families', resonates very much with the type of politics Birgit Breuel was putting forward. However, the implementation of the envisioned reforms worked out in a very different way in the UK and in Germany. Although the agenda was there, in Germany the reforms could not be implemented. Or, at least, not during the 1980s. There are several reasons for this, but I will engage just two. One of them, important both at the level of the state of Lower Saxony, as well as at Federal level, was the coagulation of a strong opposition in the form of the Green Party, constituted out of factions from the autonomist leftist movement, the Peace Movement and the environmentalists. The CDU in Lower Saxony, under the rule of Ernst Albrecht, practised a strange form of environmental politics, whereby it would heavily criticize the subsidizing of the coal industry on the one hand, but heavily support the nuclear industry on the other hand. Lower Saxony was - and still is - one of the key sites of struggle of the German anti-nuclear movement, since it is in this state that several final waste repositories and a nuclear fuel reprocessing plant were planned and some even built ${ }^{12}$. This triggered a heavy opposition towards the CDU government. And then, there was always the social democratic party, the SPD, which was lurking in the background, waiting to take back power ${ }^{13}$.

In 1990 the CDU was voted out of power in Lower Saxony and the new government was formed by a coalition between the social democrats and the Green Party. The Green Party, until then always called the 'protest party' was in power at state level in the new cabinet of the reformed social democrat Gerhard Schroeder. Birgit Breuel lost her job as minister of the state. But at the federal

\footnotetext{
12 Lower Saxony is the site of the final nuclear waste repositories Asse, Gorleben and Konrad. Asse, a salt mine, has been filled with nuclear waste during the time of Ernst Albrecht. Later it turned out that the water and salt infiltrated the barrels and made them leak. Now the waste has to be taken out again. Gorleben was planned to be the high radioactive waste repository of Germany. The plans started also during the CDU rule. After heavy protests it was given up as an idea and now Germany is looking for a new site. Konrad will be the low and medium radioactive waste repository and is currently under construction. It is supposed to be finished by 2022.

13 There is also another reason for the failure of the CDU to implement the pro-market reforms, which can be addressed here only briefly. The speed and intensity of the reforms was not shared by all leading members of the party at federal level. Besides, as Prasad (2006) argues, the structure of the party was in such a way that certain factions could actually veto decisions of the leading party members. The workers' faction of the CDU used this institutional arrangement of the party in order to block more far-reaching market reforms that were coming from the top during the 1980s.
} 
level things stood differently. The CDU was still in power, with Helmut Kohl embarking on the most important project of his political career: The German Reunification. This was also the moment when Birgit Breuel was appointed to the most important position of her career. Immediately after being voted out of office in Lower Saxony, she moved to the Treuhandanstalt ${ }^{14}$ in 1990, the public holding company that took over all the assets of the German Democratic Republic. After the previous manager of the Treuhandanstalt, Detlev Rohwedder, was assassinated in 1991, Breuel took over the position, overseeing the fate of all the state-owned assets of the former GDR. There could have been no better place than the Treuhand to really experiment with the ideas that she was supporting for two decades and was not able to implement in West Germany.

In order to comprehend the magnitude of this 'laboratory East' that the Treuhand was, one has to realize that at the time of its formation in 1990 it was 'having taken up nearly an entire national economy, was by far the largest holding company in the world, equivalent in terms of the number of its constituent firms and their employees to the twenty-five biggest corporations listed on the New York stock exchange (Dale, 2002: 112). While in the first phase the purpose of the Treuhand was to restructure the economy through a variety of ownership forms, very rapidly and with intense pressure from the federal government the agenda turned into one favouring 'shock therapy' style privatization by all means. The companies that did not survive the privatization process were considered not to be viable on the market and were shut down. The Treuhand was directly responsible for more than 10,000 companies, 25,000 real estates, several thousand vacation homes, 1,500 shops and pharmacies, 2,000 cinemas and 50\% of the entire agricultural area of the former GDR. The motto of the Treuhand was 'fast privatization, decided restructuring, cautious shutting-down' (Breuel, 1991:9). Breuel even went further and declared publicly that the Treuhand represents an opportunity for experimenting with new private ownership forms in the former GDR, such as in the field of water management, something that was a complete taboo even in West Germany, where water management was traditionally in the hands of the communes (Breuel, 1994).

By 1994, when Breuel ended her appointment as manager of the Treuhand, this process of privatization was almost complete, leaving the East German economy in full collapse. Taking stock of her experience as Treuhand manager, in a 2005 book, Breuel seemed very satisfied with the results.

\footnotetext{
14 Which means the 'Trusting Hand Agency'.
} 
Despite all the known difficulties and mistakes, the introduction of the market economy in the former GDR stands as the central success of the transformation. It is exemplary in world history. Despite all the concerns about the speed and costs of the privatization of Eastern Germany, it is without a doubt, that it enabled a decisive move towards the market economy. The central responsibility for this process was carried by the Treuhandanstalt. It accomplished the privatization of Eastern Germany so rapidly and consequently, that there was not much time left for introspection (...) (Breuel, 2005: 13)

Ironically, however, the very same privatization process created the need for a sustained subvention of the 'new federal states', something that does not fit into this reform framework at all.

We have arrived back to where we started, at EXPO 2000. Two years after leaving her job as manager of the Treuhand, in 1996, Birgit Breuel became the manager of the world exhibition. She was appointed to the position because she had already established herself the image of a person that can get things done. But she also brought with her the ideas that she had been promoting throughout her entire political career.

\section{Conclusion: The future ruins of sustainability}

Breuel turned to sustainability before exiting public life, but following the same aggressive pro-market agenda that she had been promoting throughout her entire career. A new generation of politicians and experts came into the limelight after her exit from public life in Germany. The new coalition between the SPD and the Green Party, that came to power at federal level in Germany in 1998, would end up succeeding at what the conservatives had failed to in their long stay in power. Schröder was an exemplary case of a 'third way social democrat', taking over the aggressive pro-market agenda of his conservative predecessors and taking it much further. Soon after EXPO, together with the energy transition reform and the nuclear exit, another reform took place under Schröder: the labour reform. But this path was smoothed out by a shift in the image of SPD party politics towards a more humane, consensual approach. And, most importantly, a supposedly more environmentally friendly approach. The work for this smoothing of the path had been done by public figures such as Amory Lovins and Ulrich Beck, who gave the perfect soft agenda for such a cosmopolitan, 'civil society' image of politics, purged of any real conflict of interests. Even more so, the initially radical agenda of the grassroots Greens was completely eviscerated from their party politics by the time they entered the federal government in 1998, creating the prerequisite for a government that was completely pro-market and anti-labour, but with the novel addition that this market now included a soft version of environmentalism called sustainability. 
In other words, the new government of Gerhard Schröder activated a specific understanding of sustainability, by which the capacity for protest of a large segment of the German middle classes was tamed. Simultaneously, Schröder went on a direct attack against the working class, especially those segments that were the traditional voter segment of the social democrats, and pushed through with his labour reforms (see Dörre \& Rosa \& Lessenich 2009). Gerhard Schröder, the reformed social democrat, went much further than his conservative opponents in implementing liberal market reforms in Germany. And sustainability, as it was staged in the Agenda 21 and EXPO 2000, was the ideal facilitating tool for implementing these reforms.

This article was only able to scratch the surface of a political shift that is much more complex and nuanced. It chose to focus on the discursive level of high politics in this story a la Boltanski and Chiapello (2005), where fringe matters of concern are taken up by experts and adapted for their own purposes in the dynamic process of capitalist transformation. As such, the article did not engage with the direct material and infrastructural entanglements of this transformation, which are just as interesting. But it hopes to trigger a conversation about the place that environmental concerns have, especially in a context when, globally, conservative politics seem stronger than ever. Ultimately, one provocative question that remains relates to the role that this mismanagement of sustainability by reformed social democratic governments had in this recent resurgence of right-wing politics. Related to this question is the connection between the alienation of the working classes from environmental issues - for instance through climate denial - and the double activation of sustainability and deregulation performed in the last few decades in the West by social democrats such as Gerhard Schröder.

\section{REFERENCES}

Adorno, Theodor W., and Max Horkheimer. (1973). Dialectic of Enlightenment. London: Allen Lane.

Beck, Ulrich. (1999). EXPO 2000: Schöne neue Arbeitswelt: Vision: Weltbürgergesellschaft. 2 edition. Frankfurt/Main: Campus Verlag.

Beck, Ulrich. (2000). The Brave New World of Work. Cambridge: Polity Press.

Boltanski, Luc and Chiapello, Eve. (2005). The new spirit of capitalism. London; New York: Verso.

Breuel, Birgit. (1985). Alternativen zur klassischen Wirtschaftspolitik oder alternative Wirtschaftspolitik? am Donnerstag, d. 14. Februar, Mitteilungen des ÜberseeClubs, H. 2. Hamburg: Übersee-Club. 
Breuel, Birgit. (1991). Arbeit der Treuhandanstalt: Rückschau und Perspektiven. Mitteilungen / Übersee-Club Hamburg, H. 6. Hamburg: Übersee-Club.

Breuel, Birgit. (1979). Den Amtsschimmel absatteln: weniger Bürokratie, mehr Bürgernähe. 1. Aufl. Düsseldorf, Wien: Econ-Verlag.

Breuel, Birgit. (1976). Es gibt kein Butterbrot umsonst: Gedanken zur Krise, d. Problemen u. Chancen unserer Wirtschaft. 1. Aufl. Düsseldorf, Wien: Econ-Verlag.

Breuel, Birgit. (1983). Perspektiven des Aufbruchs: aus Fehlern lernen. 1. Aufl. Econ-Forum. Düsseldorf Wien: Econ-Verlag.

Breuel, Birgit. (1994). Privatisierung Setzt Zukunftszeichen : [Der Vortrag Wurde Am 11. März 1994 Anlässlich Der Verleihung Der Bernhard-Harms-Medaille Im Institut Für Weltwirtschaft an Der Universität Kiel Gehalten] / von Birgit Breuel. Institut Für Weltwirtschaft an Der Universität Kiel. Kiel: Inst. für Weltwirtschaft.

Breuel, Birgit, and Hans-Jürgen Allert, eds. (1993). Treuhand intern: Tagebuch. Orig.Ausg., 2. Aufl. Ullstein, Nr. 36614: Ullstein-Report. Frankfurt/M Berlin: Ullstein.

Breuel, Birgit. (1999). Agenda 21: Vision Nachhaltige Entwicklung. Frankfurt/Main: Campus Verlag.

Breuel, Birgit, and Michael C. Burda, eds. (2005). Ohne Historisches Vorbild: Die Treuhandanstalt 1990 Bis 1994: Eine Kritische Würdigung. 1. Aufl. Berlin: Bostelmann \& Siebenhaar.

Breuel, Birgit, Rolf Fröhner, and Berufsverband Deutscher Markt- und Sozialforscher, eds. (1986). Marktforschung morgen - sind wir für die Zukunft gerüstet? die folgenden Vorträge wurden anlässlich des BVM-Kongresses 1986 am 2. und 3. Mai 1986 in Lüneburg gehalten. Vorträge zur Markt- und Sozialforschung, H. 12. Offenbach/M: BVM.

Clément, Gilles. (2015). 'The Planetary Garden' and Other Writings. Edited by Gilles A. Tiberghien. Translated by Sandra Morris. Tra edition. Philadelphia: University of Pennsylvania Press.

Dale, Gareth. (2002). More Shock than Therapy: Why There Has Been No 'miracle' in Eastern Germany. Socialism and Democracy 16 (2): 93-136.

Deimer, Josef. (1980). Antibürokratie: mehr Bürger als Untertan. Edited by Gerd Habermann. München: mvg.

Dörre, Klaus, Stephan Lessenich, and Hartmut Rosa. (2009). Soziologie - Kapitalismus Kritik: eine Debatte. Suhrkamp.

EXPO 2000. (2000). Die weltweiten Projekte der EXPO 2000 / Projects around the world of EXPO 2000. 2 Bände. 1. edition. EXPO 2000 Hannover.

Fukuyama, Francis. (1992). The End of History and the Last Man. London: Penguin Books. Gandy, Matthew. (2013). Entropy by Design: Gilles Clément, Parc Henri Matisse and the Limits to Avant-Garde Urbanism. International Journal of Urban and Regional Research 37 (1): 259-78.

Habermann, Gerd, and Josef Deimer, eds. (1980). Antibürokratie: mehr Bürger als Untertan. München: mvg.

Illich, Ivan. (2009). Energy and Equity. London; New York: Marion Boyrs. 
Lovins, Amory, and Peter Hennicke. (1999). Voller Energie: Vision: Die globale FaktorVier-Strategie für Klimaschutz und Atomausstieg. New York: Campus-Verlag Frankfurt/Main.

Lyotard, Jean-Francois. (1992). The Postmodern Condition: A Report on Knowledge. Theory and History of Literature, v. 10. Manchester: Manchester University Press.

Meding, Conrad von. (2016). Soll Der Holländische Pavillon Abgerissen Werden? Hannoversche Allgemeine Zeitung, May 23. http://www.haz.de/Hannover/Ausder-Stadt/Uebersicht/Niederlaendischer-Pavillon-der-Expo-2000-wird-zumRisikofaktor.

“MVRDV - EXPO 2000.” (2017). http://www.mvrdv.nl/projects/expo. [Accessed September 10].

Offe, Claus. (1984). Contradictions of the Welfare State. Translated by John Keane. 1st MIT Press ed. Studies in Contemporary German Social Thought. Cambridge, Mass: MIT Press.

Donella H. Meadows, and Club of Rome, eds. (1972). The Limits to Growth: A Report for the Club of Rome's Project on the Predicament of Mankind. London: Earth Island.

Prasad, Monica. (2006). The Politics of Free Markets: The Rise of Neoliberal Economic Policies in Britain, France, Germany, and the United States. Chicago: University of Chicago Press.

Schröder, Gerhard. (1992). Reden Zur EXPO 2000 von Gerhard Schröder. Presse- und Informationstelle der Niedersächsischen Landesregierung. 